\title{
Vállalkozók, vállalkozások és innovációk Pécsett a dualizmus korában
}

\author{
Kaposi Zoltán \\ Pécsi Tudományegyetem
}

\begin{abstract}
A TANULMÁNY CÉLJA
Megvizsgálni, hogy a 19. századi gazdasági modernizáció (a nyugati iparosodás, technikai átalakulás, gyáripar létrejötte) hogyan ment végbe Közép-Európában, s azon belül Magyarországon, Pécs városban, $\mathrm{s}$ milyen technikai innovációk jöttek létre a pécsi vállalkozók által.
\end{abstract}

\begin{abstract}
ALKALMAZOTT MÓDSZEREK
Szakirodalmi, gyártörténeti irodalom áttekintése. Gyűjteményes kötetekben megjelent források, foglalkozási és népszámlálási statisztikák, visszaemlékezések, valamint levéltári kutatásaim adatainak beépítése. Az elemzési keret az egyes vállalkozások története. Öt olyan vállalkozást mutattam be, amelyek gazdasági hatásai hosszú távon is meghatározták Pécs múködését. Struktúraelemzést végeztem, a vállalkozó és a vállalkozás rendszerét együtt vizsgálva.
\end{abstract}

\section{LEGFONTOSABB EREDMÉNYEK}

Az osztrák Dunai Gőzhajózási Társaság (DDSG) 1852-től a nagyüzemi szénbányászat elindításával, a modern technikai háttér megteremtésével a legnagyobb üzemmé vált Pécsett. A 20. század elején 4000 embert foglalkoztatott, s fejlesztéseivel (vasútépítés, villamos erőmủ stb.) a város lakossága is sokat nyert. A Zsolnay-gyár neve is hamar összeolvadt Péccsel. Zsolnay Vilmos technikai innovációival (eozin, pyrogránit stb.), termékeivel világhírú vállalkozóvá vált. A dualizmus korában alapozódott meg a „pécsi kesztyü" fogalma. Hamerli János hozta létre az első kesztyűgyárat az országban. Az Angster-orgonák 150 éve szólnak a világon. Az Angster József alapította vállalat felfutása a 19. század vége felé ment végbe, s technikailag Európában a csúcsot jelentette. Az igen sokoldalú Engel Adolf vállalkozásai föleg a pécsi fürdóélet (Balokány), a faipar, az építőipar és a komlói szénbányászat elindítása kapcsán hozott sokat.
\end{abstract}

\section{GAZDASÁGPOLITIKAI JAVASLATOK}

Az innovációkat és a gazdasági fejlődést elősegítette a korszakra jellemző liberális gazdaságpolitika, a szabad vállalkozói környezet, a Monarchia hatalmas piaca, a technikai kreativitás, a vállalkozói attitüd léte, $\mathrm{s}$ a lakossági igényszint emelkedése.

Kulcsszavak: Pécs város, vállalkozó, vállalkozás, innováció, fejlődés

Köszönetnyilvánitás: Jelen publikáció az Európai Unió, Magyarország és az Európai Szociális Alap társfinanszírozása által biztosított forrásból az EFOP-3.6.2-16-2017-00017 azonosítójú „Fenntartható, intelligens és befogadó regionális és városi modellek" címủ projekt keretében jött létre.

DOI: 10.15170/MM.2020.54.KSZ.I.06 
INNOVÁCIÓ ÉS GAZDASÁGI FEJLŐDÉS NYUGAT-EURÓPÁBAN A 19. SZÁZADBAN INNOVATION AND ECONOMIC DEVELOPMENT IN WESTERN EUROPE IN THE NINETEENTH CENTURY

A nemzetközi gazdaságtörténeti szakirodalom a „hosszú 19. századot” a modernizáció korának tartja. Legfontosabb jellemzője az volt, hogy a régi tradicionális gazdasági és társadalmi kötöttségek leépültek, s helyettük új, alapvetően piaci jellegú viszonyok alakultak ki (Abel 1935). Ez leghamarabb Angliában ment végbe, de a piaci viszonyok hamar megjelentek Európa más területein is (Bairoch 1976). Másfélszáz éve foglalkoztatja a szakembereket, hogy mi okozta a változásokat; melyek voltak azok a gazdasági és társadalmi kontextusok, amelyek révén az új gazdasági modell létrejöhetett. Az egyértelmű választ azért is nehéz megadni, mert szinte mindegyik országban voltak olyan jelenségek, amelyek helyileg egyedivé tehették a változásokat (Cameron 1989; Crafts 1985; Ránki 1983).

A nyugat-európai gazdasági átalakulásban nagy szerepe volt az egyre gyakoribb innovációknak, amelyek szinte mindegyik ágazatban megjelentek. Ilyen innovációknak tekinthetjük a technikai találmányokat, az új termelési módszereket, azokat a nyersanyagforrásokat, amelyekkel új iparágak jöhettek létre, a gyári termelés meghonosítását, valamint az Európán kívüli világ piacainak bevonását (Cameron 1989; Landes 1969). Az innováció nem más, mint kreatív rombolás, amelynek célja az addigi egyensúly megszüntetése, s egy érzékeny, minden területre kiterjedő gazdasági szelekciós folyamat kialakítása (Schumpeter 1980). A változások középpontjában a kockáztató, kalkuláló, a csak hosszú távon megtérülő beruházásokat is felvállaló vállalkozó áll, akinek döntő szerepe volt a racionális, piaci, haszonelvű gondolkodás meghonosításában (Sombart 1909).

Kérdés, mely gazdasági ágakban látszanak leginkább az innovációs folyamatok? Kétségtelenül sok területe volt az átalakulásnak, a teljesség igénye nélkül kiemelünk néhány fontosabbat.

1. Az 1720-as évektől az angol és holland agrártermelés gyors ütemben átalakult. A gyorsan szaporodó népesség keresletének kielégítéséhez tömegtermelésre volt szükség, amihez fel kellett számolni a hagyományos gazdálkodási rendszert (Slicher van Bath 1963; Schultz 1964).
Az 1730-as évektől az enclosure révén megteremtették a nagyüzemi gazdálkodás alapjait, hiszen a tagosított nagybirtokon lehetőség nyílt beruházásokra (Turner 1989). Angliában 1835-ben megjelent az első gőztraktor, amellyel már mélyszántást és jobb talajforgatást lehetett végezni; a gőzcséplőgépek, a vetőgépek, az aratógépek, a kévekötőgépek, a vasekék, a vasboronák látványosan növelték a mezőgazdaság termelékenységét (Overton 1996; Estók 1996; Orosz 1971). A vegytan és a biológia fejlődése révén egyre többet tudtak a talajról, a növényekröl, az állatokról. $\mathrm{Az}$ üzemtani ismeretek is egyre jelentösebb szerephez jutottak a gazdálkodásban (Tóth 1982; Thaer 1810).

2. A tudományos kutatásokon alapuló fejlődés az ipar területén érzékelhető leginkább. Régóta próbálkoztak már azzal, hogyan lehetne a vasolvasztáshoz szükséges faszenet más fütőanyaggal kiváltani. Erre a szén kokszosítása teremtett lehetőséget. A 19. század közepén tökéletesítették a vasolvasztás módszereit is. A 19. század második felében a nehézipar már ontotta az alapanyagot, amit a gépipar, közlekedési ipar, a mezőgazdaság egyre nagyobb mennyiségben tudott felhasználni. A fejlődés hatására szinte minden országban hatalmas tömegủ munkaerőt tömörítő nehézipari vidékek alakultak ki (Taylor 1988; Kaposi 1996).

3. A jó minőségủ vas- és acélgyártással lehetőség nyílt nagynyomású gőzgépek létrehozására, amelyeket a gazdaság több területén tudtak használni. A gőzgép robbanásszerủ terjedése a 19. század elején indult meg. A gépipar, a közlekedési ipar, a textilipar és a mezőgazdaság hatalmas keresletet biztosított. Számos technikai fejlesztés révén a dugattyús gőzgép a 19. század meghatározó találmányává vált, $\mathrm{s}$ egészen a robbanómotoros rendszer elterjedésig uralta a piacot; legnagyobb hatását a gőzmozdonyok révén érte el (Landes 1969; Taylor 1988).

4. A textilipar technikai és üzemszervezési innovációi már az 1730-40-es évektől létrejöttek. A szövés és a fonás gépesítése, később vízerővel, majd gőzzel történő gépmeghajtás a hagyományos kézmüipart háttérbe szorította. A kereslet egyre inkább a tengerentúli gyapot feldolgozásából származó pamuttermékek iránt 
nőtt meg, ezért a mechanikai fejlesztések is alapvetően ez irányban történtek. A textilipar hatalmas tömegeket mozgatott meg: a 19. századtól kezdve a több ezer munkást, főleg az olcsó női- és gyerekmunkát használó gyárak gomba módra szaporodtak a szigetországban; számos új regionális iparközpont jött létre (Berend Ránki 1987).

5. A növekvő termékmennyiség szállítási igénye új kihívások elé állította a közlekedési ágazatot. Megújult a szárazföldi közúthálózat. A közutakkal párhuzamosan indult meg a folyami csatornák kiépítése: az európai mintegy $10.000 \mathrm{~km}$ csatornahálózat az 1840-es évekig megfelelő szállítási kapacitást biztosított. A tengeri hajózás is sokat fejlödött Kezdetben még a fából készült hajók szaporodtak; de a jövő itt is a vasiparé volt. A 18. század középső harmadában megépültek az első vashajók, majd pedig a gőzhajó feltalálása és technikai stabilizálása után új korszak kezdődött. A megújulás legfontosabb ága a vasút volt: a 19. század második felében hihetetlen gyorsan nőtt a vasúthálózat, s 1914 előtt már 330.000 km vasút müködött Európában. Fél évszázad alatt a vasút vált a legfontosabb közlekedési eszközzé: a vasút jóval gyorsabb volt, mint a csatornán vagy közúton történő fuvarozás. A vasút óriási megrendeléseket biztosított a különböző iparágaknak és más ágazatoknak; úgy is mondhatnánk, hogy a gazdaság nagy része a vasút felé fordult. (Taylor 1988; Kaposi 1996; Berend - Ránki 1987)

\section{ALKALMAZKODÁS ÉS FELZÁR- KÓZÁS: KÖZÉP-EURÓPA LEHE- TŐSÉGEI \\ ADAPTATION AND CONVER- GENCE: THE POSSIBILITIES OF EASTERN EUROPE}

Kérdés persze, hogy a fent vázolt modernizációs folyamatból mi jelent meg Közép-Európában, a Monarchia, s azon belül Magyarország területén. A Habsburg Birodalom a 20. század elején Európa második legnagyobb területi kiterjedésú, s negyedik legnagyobb lakossággal rendelkező országa volt. A birodalom a 19. században gazdaságilag gyorsan fejlődött. Területét háborúk 1850 után alig érintették, így a világgazdasági konjunktúrák ide- jén jelentősen emelkedett az egy főre jutó termelés, s komoly életszínvonal-növekedés is végbement (Komlos 1990). Ennek eredményeként a Monarchia a 20. század elejére egy közepesen fejlett országgá vált. A birodalmon belül persze jelentős gazdasági különbségek voltak: a fejlett osztrák és cseh tartományok gazdasági színvonalához képest a bukovinai, dalmát stb. vidékek nem érték el annak harmadát-negyedét sem (Berend - Ránki 1987).

A gazdasági fejlődéshez szükség volt egy tudatos, a fontosabb nyugati folyamatokra figyelő gazdaságpolitikai rendszerre, aminek lényege a modern technikák átvétele, a vasútfejlesztés felgyorsítása és a birodalmon belül szabadkereskedelem létrehozása volt. Az elképzelés fontos eleme volt az elzárkózás: a fejlett nyugati országok gazdasági versenyétől magas vámokkal védték meg a birodalom piacát (Kövér 1982; Kaposi 2002). A század közepén felszámolták a két országot elválasztó belső vámhatárt, amivel szabad termékáramlást biztosítottak Ausztria és Magyarország között. Bevezették az osztrák adórendszert. Elrendelték a telekkönyvezést, amely révén a földtulajdonlásban világos viszonyokat teremtettek. Iparszabadságot hirdettek (Szabad 1978).

A dualizmus idején Ausztria-Magyarország több volt már, mint egyszerủ vámunió: igazi közös piacként müködött; teljes monetáris integrációval és részleges adóunióval. Nagy jelentősége volt a magyar-osztrák közös vállalatok szaporodásának, amelyek föleg a nagyiparban terjedtek el (Katus 1989). Tény, hogy a Monarchia gazdasági fejlödése a 19. század második felében a korábbiakhoz képest igen gyors volt, ezt mind a gazdasági növekedési, mind az életszínvonal változására utaló mérések bizonyítják (Good 1986). A növekedés a nagyobb régiókban eltéró volt. A birodalmon belüli különbségek csökkentek; Magyarország egy före jutó jövedelme a birodalmi átlag körül mozgott (Berend - Ránki 1987).

\section{PÉCS GAZDASÁGI HELYZETE A 19. SZÁZAD KÖZEPÉN THE ECONOMIC SITUATION OF PÉCS IN THE MIDDLE OF THE NINETEENTH CENTURY}

Nézzük meg a továbbiakban, hogy a gyorsan változó közegben milyen volt Pécs szabad királyi város gazdasági és társadalmi helyzete a 19. század közepén. Pécs a vizsgált korszakban a Dél-Dunántúl legnépesebb városa volt. Népessége a 18. század eleje óta gyorsan nőtt: 1828 körül 11.300, 
míg 1850 körül 15.300 fö lehetett a város lakossága (Nagy 1828; Fényes 1851). Különösen felgyorsult a növekedés 1850-1870 között, amikor 20 év alatt a népesség mintegy 24.000 főre emelkedett. Ez a növekedés a térségben persze nem volt egyedülálló. Pécs lakossága több mint 90\%-ban katolikus volt (Katus 1995).

Ami különlegessé tette Pécs helyzetét, az a regionális központi jellege volt. A Mecsektől délre jelentős agrárvidékek feküdtek: a szlavóniai, a bácskai területekröl, avagy a török birodalomból érkező kereskedelem nagy része érintette Baranyát. A város méretével, szálláslehetőségeivel fontos állomásává vált az átmenő forgalomnak. Piackörzetének nagyságával Pécs az 1828. évi országos összeírás adatai szerint Pest-Buda után az ország második legnagyobb gazdasági központja volt, amelybe 371 település tartozott (Bácskai 1988). A forgalmazás szélesedését nagyban segítette, hogy három országút futott össze Pécsett. A kereskedők száma folyamatosan szaporodott a városban: a város évi négy országos vásárt tarthatott, ugyanakkor bővült a belső ellátást biztosító bolthálózata (Antalffy 1982).

A pécsi gazdaság egyik legfontosabb sajátossága a szőlő- és bortermelésben fogható meg. A város határából mintegy 15\%-ot tett ki a szőlővel beültetett terület. Az 1850-es évekre már mintegy 1900 holdat tett ki a szőlők területe Pécsett (Kovács 1973). Úgy számolhatunk, hogy a 15.000 fós lakosság esetében a mintegy 7000-8000 felnőtt esetében egy före 7-8 hl bor adódik, ami nyilván jóval túl van az egy fó által fogyasztott mennyiségen. A szőlő és a bor több volt a pécsi emberek életében, mint egyszerü fogyasztható termék vagy jövedelmi forrás. A korabeli városok szinte mindegyikében a polgári lét szimbólumértékü eleme volt a szőlő, s a szőlőművelés egyes fázisaihoz köthető életmód (Kaposi 2017. 11.).

Érdekes képet mutat a 19. század közepe felé a pécsi ipar. Pécsett sokáig a kisüzemi iparrendszer dominált. Az ipar fejlödése ugyanakkor a gyorsan növekvő népesség kereslete miatt csakis technikai innovációkkal, avagy a ráfordítások és a tőkeigényesség emelésével volt lehetséges. Egyéni szakértelemmel, remekmunkák készítésével ezt a helyzetet a jövedelemtermelés szempontjából még fenn lehetett tartani, de az előrelépés csakis az üzemméret növelése és a tömegtermelés felvállalása felé mutathatott. Az 1840-es évektől kezdve számíthatjuk a pécsi ipar megújulását, amikor is megjelentek az első gyárak is. Közöttük volt már sörfőzde, likőrgyár, szivargyár, gazdasági gépeket gyártó üzem, papírgyár (Kaposi 2017. 13-14). Pécsett az első cukorgyár 1844-ben jött létre Linberger Gott- lieb Gyula Pozsonyból származó vállalkozó által. A gyár az első évben már 19.000 mázsa cukorrépát dolgozott fel, amelyböl 800 mázsa cukrot nyertek (Kopasz 1968). 1844-ben kezdte meg müködését az első vasgyár, amely már két gőzgépet is használt a termeléshez. A vasércet Gömörből hozták, a szenet a Mecsekben bányászták. A vállalkozás részvénytársaság formájában szerveződött, amiben a Gömör megyei Concordia egyesületnek és Madarász András gömöri vasgyárosnak volt nagy szerepe (Remport 1996).

Pécs gazdasági életében folyamatosan erősödő szerepet játszott a szénbányászat. Eleinte főleg a harangöntők, a rézmüvesek stb. használtak szenet ipari célokra. A városi polgárok esetében saját birtokán mindenki szabadon rendelkezhetett az ott talált szénnel. A szénforrások főleg a város keleti részén lévő Lámpás-völgy vidékén fordultak elö nagy számban (Babics 1952). Egyre többen foglalkoztak birtokaikon szénásással, s a termék értékesítésével. Sokan voltak, akik felismerték a szén ipari célokra történő felhasználási lehetőségét. Az első magán-kitermelési munkák az 1780-as években indultak meg (Babics 1952). Azon földek értéke, ahol szenet találtak, gyorsan emelkedett, s a polgárok igyekeztek ilyen földekre szert tenni. A nagyobb széntelepek viszont a városon túli szabolcsi és a somogyi területeken helyezkedtek el, amely földek tulajdonosa a pécsi Székesegyház volt. Az egyházi tulajdonos a bányákat bérbe adta. A székesegyház uradalmi szénbányáiban 1810-1844 között 369.000 q kőszenet termeltek ki és értékesítettek, vagyis évente 10.540 mázsát (Pálfy 2002). Sikerrel jártak a kísérletek az 1820-as években a kitermelt szén kokszolására vonatkozóan, ami alapját képezhette a későbbi vasiparnak. A szénbányászat a század közepén már fontos részét képezte Pécs gazdaságának.

\section{Pécsi ipari vállalkozók és vállalkozások (1850-1914) \\ Industrial Entrepreneurs and Enterpri- ses in Pécs (1850-1914)}

A korábbi időszakokhoz képest az 1850-60-as években jelentős gazdasági fejlődést érzékelhetünk Pécsett. Ezt sok jel mutatja. Szembetünő a kereskedők számának megugrása: az önkényuralmi időszak végén már 160 főfoglalkozású kereskedő élt a városban, ami nyilván szoros kapcsolatban van a korabeli, országosan is megfigyelhető gazdasági felvirágzással (Gründerzeit). Szaporodtak a vállalkozások, számos új gyárat alapítottak, virágzott a kisipar. Ezek, s más jelek azt mutatják, hogy a 
reformkorban megindult átalakulás az 1850-es években felgyorsult, ami egyben alapját képezhette a dualizmus idején bekövetkezö dinamikus fejlődésnek. A továbbiakban megnézzük, hogy az első világháborúig terjedő időszakban a pécsi vállalkozásoknak melyek voltak azok a fontosabb esetei, típusai, amelyekben a tulajdonosok jelentős innovációkat tudtak létrehozni, s amelyek révén hosszú távú gazdasági sikerekre számíthattak. Öt olyan innovatív vállalkozást mutatunk be, amelyek eredményeikkel beírták magukat a pécsi gazdaság történetének képzeletbeli aranykönyvébe.

\section{A külföldröl jött nagyüzem hatása: a Dunai Gözhajózási Társaság The Effect of a Foreign Corporation: First-Danube-Steamboat-Shipping Company}

A pécsi gazdaság fejlődésére az egyik legnagyobb hatást minden bizonnyal a Dunagőzhajózási Társaság (DGT; DDSG) gyakorolta. Az osztrák tulajdonban lévő DGT folyamatosan bővítette dunai szállítási hajóparkját; 1850-ben 48, 1860-ban már 120 gőzössel rendelkezett, ami sokáig meghatározó volt az Ausztriába irányuló gabonakivitel szempontjából (Huszár 2013. 80). A nagyvállalat szénszükséglete folyamatosan növekedett: egyértelmű volt, hogy érdemesebb egy szénkitermelési vertikumot kiépíteni, semmint külső termelőktől vásárolni. Így 1852-ben a DGT Pécs északkeleti részén (később Pécs-bányatelep) részén lévő földeket megvásárolta, ahol egy évvel később létrehozta az első bányaüzemét (András-akna). A bányát 1853 után folyamatos, kisebb nagyobb vásárlásokkal és bérleményekkel megnövelte. Ennek során jó néhány pécsi polgár bányája került át a Társasághoz. A DGT 1854-ben Pécs várostól bérbe vette, majd 1857-ben megvette a Káposztás-völgyi birtokot; ugyanekkor vásárolta meg a városnak a Nagybánya-völgyben lévő birtokát is. 1855-ben Riegel Antaltól vette meg a Karolina-bányát, 1864-ben Czvetkovits Ferenctől az Istenáldás-bányát, $1867-$ ben pedig a híres pezsgőgyáros Littke Lörinctől szerezte meg bányáját a Feketehegy bányatársulat birtokával együtt (Babics 1952. 26-30).

A DGT-nek meg kellett oldania a szén elszállítását is. A korabeli gazdasági élet egyik legnagyobb problémája a szállítás költsége volt, az országban alig volt még vasút. 1852-ben kezdték meg a vasúti építkezést az országúti távolságnál másfélszer hosszabb Pécs-Villány-Mohács vonalon. Először (1854-ben) a Pécs-bányatelep - Üszögpuszta közti 6 km-es szakasz készült el, ezt még a Társaság számlájára a bécsi kormány építette, hiszen a centralisztikus elképzelésekkel rendelkező kormányzat politikájába jól beleillett az osztrák tulajdonú DGT erösítése. Üszögpuszta délkeleten közvetlenül határos volt Péccsel, a hatalmas uradalom ekkor a bécsi bankár és nagykereskedő Biedermann család két tagjáé volt (Kaposi 2019/a. 133), Üszögön kezdetben egy tároló pályaudvart építettek Az évtized közepén viszont változott a központi vasútfejlesztési koncepció, így most már a DGT-nek kellett saját forrásaival az Üszög-Mohács közti szakaszt befejezni. A nagy nehézségekkel járó vasútépítkezés 1857-ben fejeződött be: ekkor adták át a MohácsPécsi Vasút 56 km-es vonalat. Az első „,szénvonat” 1857. május 2-án érkezett meg Mohácsra. Ezzel a vasúttal a DGT gyorsan elérhető, biztonságosan szállítható, olcsó, illetve jó minőségü szénhez jutott hozzá. A DGT a vasútvonalat kizárólagosan áruszállításra tervezte, eleinte nem kívánták azt személyforgalmazásra, vagy más áru szállítására használni. Kétségtelen, hogy a korábbi pécsi, szederkényi stb. fuvarosok elveszítették a szénszállításból eredő jövedelmeiket, viszont a vasútépítés, s később a működtetés, illetve a pécsi rakodó és a mohácsi kirakodó állomás munkaerőigénye javított a foglalkoztatási helyzeten (Erdősi 1986.).

Mit hozott még az első vasúton kívül a DGT Pécsnek? Leszögezhetjük: nagyon sokat. A nagyvállalat az 1860-70-es években tovább terjeszkedett; egyre több területet vásárolt meg, vagy vett birtokba. A 20. század elején már 759 holdnyi földdel rendelkezett a társaság. (Pécs ezer éve 1996. 191.) Ezzel egyre inkább bővítette a foglalkoztatást városban és a város melletti falvakban. (DGT 1894) A század végén Pécsbánya-telepnek már 4300 lakosa volt, amely egyben az V. kerületévé vált a városnak. (Pécs ezer éve 1996. 181.) Tény ugyanakkor, hogy a társaság legnagyobb bányaüzemei a Pécs melletti Szabolcs, Somogy és Vasas falvak területén feküdtek. Köztük jelentős volt az a terület, amit a Székesegyház uradalmától béreltek 50 évre. Az egyházi intézmény ezzel hatalmas bányabérleti díjhoz jutott hozzá, amelyből Dulánszky püspök finanszírozhatta a székesegyház újjáépitését, majd pedig a meghosszabbított szerződés révén az 1920-as években a Pius templom és az interntátus felépítését (Kaposi 2019/b). Az is tény, hogy bár a bányák többsége Pécsen kívül volt, a nagyvállalat központja a városban, a Mária utca 5. száma alatt épült föl. Nem felejthetjük el azt sem, hogy a mintegy 4000 (köztük kb. 900-1000 pécsi) bányász az átlagosnál jobban kereső ember volt, ami hatalmas lehetőséget biztosított a pécsi termelőknek és kereskedőknek bevételeik növelésére. S végül említsük meg, hogy a nagyvállalat, mint szervezet is kilógott 
a sorból: racionálisan müködő, profitorientált, többségében sokáig külföldi munkavállalókkal müködő cég volt, amelynek technikai fejlesztései, újításai átkerültek a pécsi közéletbe is, így például Pécs város 1918-tól a DGT újhegyi erőművéből kapta az áramot (Kaposi 2006. 120).

\section{A kereskedelemtől az ipari innovációig: a Zsolnay \\ From Commerce to Industrial Innova- tion: The Zsolnay}

Pécs ipari rendszerében a „Zsolnay” fogalma különleges szimbólummá vált az idők során. Megtestesíti a tőkés vállalkozó prototípusát, a puritán szemléletü, de a megújulást lázasan kereső sikeres nagyvállalkozót, aki egész életét a vállalat sikerének és a müvészi önkifejezésnek rendelte alá; a müvészi tevékenységet felvállaló, de mégis nagyvállalati struktúrában müködő rendszert és a magas szintü munkavállalói szaktudást (Jávor 2004).

Zsolnay Vilmos apja kereskedőként élt Pécsett, a középpolgárság felső részéhez tartozott, Fő téri üzlete, annak széles árukínálata s jövedelmezősége lehetővé tette népes családja eltartását, s fiai taníttatását. A házasságból hat gyermek született. Apjuk a fiúknak 10.000-10.000 forintos örökséget juttatott, s valamennyinek szakmát adott a kezébe (Jávor 2004). A fivérek közül 1828-ban másodikként látta meg a napvilágot Zsolnay Vilmos, a későbbi nagyvállalkozó. Az elemi iskola után apja rövidáru-nagykereskedésében inaskodott, 15 éves korában megkapta tanonclevelét, majd pedig kereskedelmi tanulmányokat folytatott a bécsi Polytechnisches Institutban. Végzése után Bécsben kapott állást egy díszmüárusnál, de a forradalom idejében már újra Pécsett, apja üzletében dolgozott. Házasságából egy fiú (Miklós) és két lány (Júlia és Teréz) született (Rúzsás 1954. 46).

Zsolnay Vilmos kezdetben nem foglalkozott kerámiagyártással. Apja 1853-ban átadta neki Fő téri üzletét (Zsolnay 1974. 17). A kereskedői szakma széles horizontú tevékenységet jelentett abban az időben, így Zsolnay sok mindennel foglalkozott. Az önállósodása után 1854-65 között a legkülönbözőbb gazdasági ágazatokban tevékenykedett. Egyrészt az apjától felvett 5000 forintos kölcsönből kibővítette Fő téri kereskedését, ennek érdekében megvette a mai Király utca 1. szám alatti telken álló házat, amit aztán átalakítva megnagyobbíttatott, s egyben állandóan bővítette az áruválasztékot. A „Bazár” 1880-ig Zsolnay Vilmosnak biztos megélhetést $\mathrm{s}$ későbbi gyára létrehozásához fejlesztési forrásokat biztosított. A Bazárt 1880-ban eladta (Mattyasovszky-Zsolnay 1999). Az 1850-es években a borkereskedelem is bekerült a repertoárba: osztrák területekre és horvátországi városokba is szállított bort. Zsolnay a vasútépítésből is megpróbált hasznot húzni: az Üszög - Pécs közti vasút megépítésére vállalkozott Zsolnay Miklós és társasága (Rúzsás 1954). Az iparral szinte véletlenül került kapcsolatba: bátyja, Ignác lukafai agyagáru-kisüzeme eladósodott, amit 1863-ban Vilmos kölcsöne mentett meg a csődtől; majd pedig Ignác 1865-ben kénytelen volt eladni az üzemet testvérének. Az üzem átalakításával 1868-ban hozta létre Zsolnay Vilmos az „Első Pécsi Cement Chamotte és Tüzbiztos Agyagáruk gyára” üzemét (Rúzsás 1954. 49).

A kereskedőből nagyiparos vállalkozóvá vált Zsolnay Vilmos 1900 márciusában halt meg. Az életpálya a gazdasági sikerek mellett tele volt közéleti elismerésekkel. Pécs szabad királyi város díszpolgára lett, megkapta a Ferencz József-rend középkeresztjét, a II. oszt. Vaskorona-rendet, a francia becsületrendet, a belga kir. Lipót-rend lovagkeresztjét és még számos egyéb kitüntetés tulajdonosa volt (Romváry 2011). Halála a gyár müködése szempontjából nem okozott jelentősebb törést, aminek oka az volt, hogy életkora elörehaladtával egyre inkább bevonta fiát, Miklóst az üzlet működésébe. Miklós az 1890-es években átvette a legfontosabb vezetői posztokat, 1897-töl pedig mindenben társként jelent meg, az üzleti döntések már csak az ő egyetértésével születhettek meg.

Zsolnay Miklós eltérő alkat volt, mint apja. A visszaemlékezések szerint hiányzott belöle az a múvészi hajlam, amely apját és nővéreit jellemezte. Viszont igen jól értett az üzlethez (Zsolnay 1974. 178). Ő már megváltozott világban nevelkedett. Ha apját nagy „alapítónak” tekinthetjük, akkor Miklóst igazi menedzseralkatnak. Pályafutását kereskedelmi értékesítőként kezdte, az 1880-as évektől ő irányította a külkereskedelmet. Járta a világot, piacokat kutatott fel, ahol pécsi gyár termékeit el lehetett helyezni. Jellemző emberi vonásai is eltértek a testvéreitől. Apja halála után az ő kezében vált igazán sikeres nagyvállalkozássá a Zsolnay-gyár. A közmegbecsülésnek örvendő ember apjához hasonlóan halmozta a kitüntetéseket, amelyek mellett a főrendi ház tagja lett (Vargha 1999).

Zsolnay Vilmos a különböző üzleti tevékenységeit egyértelműen a kerámiaüzem fejlesztése alá rendelte. Ebben az időben kiszélesedett a hazai piac. A pécsi vállalkozó számára lényeges volt, hogy túllépjen a hagyományos, a tapasztalati-gyakorlati módszerekkel történő termék-előállításon. Az alapanyagok rendszeres vizsgálata, az égetés módszerének folyamatos megújítása, a mázak és masszák 
biztonságos összehangolása révén egyre szélesebb termékskálával lehetett a vásárlóközönséget megcélozni. Zsolnaynak az előrelépéshez tanulmányoznia kellett az európai gyártástechnológiákat, s mivel önmaga vegytani-kémiai elöismeretekkel nem rendelkezett, a kezdeti években megpróbálta indulási hátrányait jó szakemberek alkalmazásával kompenzálni (Rúzsás 1954. 29, 62-66). A folyamatos kutatás és kísérletezés egyre inkább az életévé vált.

Kedvező volt Zsolnay számára a Pécsett, illetve a Pécs melletti területeken található nyersanyag. A helyi alapanyag lehetővé tette, hogy a porcelánnál kevésbé finom, de igen tartós fajanszot elő tudja állítani. Állandóan újabb és újabb agyaglelőhelyeket keresett; azokat a telkeket, amelyek biztos nyersanyagforrást jelentettek általában megvásárolta (Zsolnay 1974. 30). Az eljáráshoz Zsolnay az olasz technikát vette át, miszerint az edényeket korongon formálták, majd alacsony tüzön kiégették, utána ónmázkeverékbe mártották, száradás után festették, s végül magas hőfokon kiégették. Mivel a 19. század második felében a piacot és a közgondolkodást a porcelán uralta, így Zsolnaynak a fajansztechnikát folyamatosan finomítani kellett, s a végterméket közelebb kellett vinni a porcelánhoz. Az eljárásban a csúcspontot 1877-re érte el, amikor sikerült elóállítania a róla elnevezett keménycserepet, amit ő porcelán-fajansznak nevezett el (Rúzsás 1954. 75). Ez porózus anyag volt, amely ellenállt a külső mechanikai hatásoknak, nem voltak benne hajszálrepedések, mint a porcelán esetében. Az így létrejött munkadarabokat festették és lágy porcelánmázzal vonták be, majd pedig kiégették. Az eljárást Zsolnay magastűzű zománctechnikának nevezte (Zsolnay 1974. 66). Ezzel a technikával aratott az 1878. évi párizsi világkiállításon sikert. A későbbiekben a bevonatkészités terén Zsolnay még messzebb jutott. 1883-ban hozta létre az ún. zsugormázat, 1885-re kidolgozta az olajfényú mázakat, de az igazi nagy elörelépés az eozin (fémfényű máz, lüszter) lett, amit 1893-ra sikerült kikísérletezni. Az eozinos eljárás során a kiégetett cserepekre fémoxidos vegyületet festettek, amit aztán vörösizzásig hevítettek, így a fémoxidból kivált az oxigén, s a munkadarabokon visszamaradt egy fémfényű máz (Zsolnay 1974. 176-177). Ezeket az eljárásokat elsődlegesen a használati és díszedény-gyártás területén tudták alkalmazni.

Az újitások azonban nem álltak meg: a kutató nagyiparos újabb és újabb területekre volt képes behatolni találmányaival, eljárásaival. A gazdaság egyre nagyobb igényeket támasztott iparilag is hasznosítható termékek iránt. Zsolnay 1875-77 között fajanszmasszából előállított szigetelőket gyártott, amivel a porcelán-szigetelőket kívánta kiváltani, egy évtizeddel később aztán áttért a porcelánból készült szigetelők gyártására (Rúzsás 1954. 79). Zsolnay gyára képes volt az építőipar számára is új termékeket előállítani. 1884-ben önálló részleggé vált a csőgyár. Az 1880-as években elindult a kályhagyártás is. 1891-től gyártották külön részlegben a falburkoló-csempéket és a padlólapokat. 1895-ben kezdték meg az épületkerámia, a pirogránit termelését, amely a vállalkozó nagy sikerét hozta (Rúzsás 1954. 60). Közismert, hogy a Kárpát-medence kontinentális éghajlata számos építőanyagra igen rossz hatással van. A pirogránit viszont fagyálló, saválló, s ugyanakkor könnyen formálható (Pécs Lexikon 2010. 2. 157).

Zsolnay Vilmosnak nagy tervei voltak. Piacként a Monarchia vámközösségi területe adott volt, de azon túl is jelentős területeket tudott meghódítani. Ehhez viszont állandó üzembővítésre volt szükség. Egy igen érdekes vállalkozói modell jött létre. Bár erre az időre mind a helyi, mind az országos bankrendszer kiépült, Zsolnay nem kereste a banki hiteleket, hanem önfinanszírozással próbálta meg fejlesztéseit irányítani. Ha mégis külső tőkeforrásokra volt szüksége, akkor elöszeretettel vett inkább kölcsön pénzt ismerősöktől, akikben tökéletesen megbízhatott (Rúzsás 1954. 90). Esetében olyan vállalkozót láthatunk, aki az elért nyereséget próbálja meg visszaforgatni a vállalkozásba. Emiatt persze a gyár fejlődése vontatottabb volt, mintha bankok finanszírozták volna, viszont Zsolnay számára az üzleti kockázatot mindez csökkentette. Zsolnay személyes életvitele is visszafogott volt, bár anyagilag messze kiemelkedett társadalmi csoportjából, mégis tartózkodott a reprezentatív kiadásoktól (Zsolnay 1974. 113).

Zsolnay Vilmos számára lényegesek voltak a versenyszerủ megmérettetések, amire a dualizmus korában a legjobb alkalmat a nagy kiállítások jelentették. Elöször az 1873-as bécsi kiállításon tünt fel termékeivel, ahol díszmúárujának eredetisége felkeltette a külföldi szakemberek figyelmét, s annyi megrendelést kapott, hogy növelnie kellett gyára termelői kapacitását (Rúzsás 1954. 83). Többek között Angliából, Franciaországból, Oroszországból, sőt még az USA-ból is kapott megrendeléseket. Zsolnay az 1878. évi párizsi világkiállításon való szereplésével vált ismert gyárossá (Várady 1896. 612). A pécsi gyáros számára a hazai vásári-kiállítási megmérettetés ideje 1885-ben jött el. Ez volt az az alkalom, amikor hazai környezetben, valóban reprezentatív környezetben mutathatta be termékeit. (Bobrovszky 1971. 31-36.) A kiállítás arról győzte meg a szakembereket, hogy a modern müvészi iparban a fajanszé az elsőség, s ebben Zsolnay Vilmos kiemelkedett kortársai közül. 
Miután a századfordulón Zsolnay Miklós átvette a gyárat, megkezdődött a dinamikus terjeszkedés. Az új tulajdonos nagyvonalú terveiben a Monarchia és a Balkán területén a monopolpozíció megszerzése szerepelt. Egyre több hazai kisebb-nagyobb porcelán-és fazekasipari cég került Zsolnay Miklós befolyása alá (Vargha 1999. 222). Zsolnay Miklós a megszerzett tőkéjét egyre több intézményben kamatoztatta, de voltak pénzügyi érdekeltségei a nagy biztosítóknál, rendelkezett számos pécsi ipari részvénytársaság értékpapírjával, de több Pécsen kívüli ipari társaság értékpapírját is bírta (Rúzsás 1954; Vargha 1999). A javuló gyári eredményességet és a külső vállalkozások jövedelmezőségét mutatja az az adat, ami szerint 1915-ben akkori számítások szerint Zsolnay Miklós gyári vagyona 7.356.000 koronát, míg a vállalati értékpapírjai kb. 2 millió koronát tettek ki (Rúzsás 1954. 149; Vargha 1999. 224). Különösen a háborút közvetlenül megelőző időszakban ugrott meg a gyár össztermelésének nagyságrendje, amit jól mutat, hogy míg 1900 körül, 1,1 millió korona volt az összetermelés értéke, addig az 1911-12-ben 3,1 millió koronára emelkedett (Rúzsás 1954. 245. alapján).

1872-ben még csak 30-35 föt dolgozott Zsolnay üzemében (Zsolnay 1974. 32). Szórt adatok alapján úgy tünik, hogy az 1878 évi párizsi világkiállítás sikere után gyorsulhatott fel a dolgozók számának növekedése; 1882-ben már 460-an dolgoztak a gyárban. A háború előtti években már mintegy 800 főt foglalkoztatott a vállalat (T. Mérey 1999. 21). Saját ágazatát tekintve a Zsolnay-gyár nemcsak Magyarországon, hanem a Monarchia egészén belül is egyedülálló volt, hiszen a három, Magyarországon kívüli legnagyobb kerámiagyárban 1901 ben összesen 327 dolgozót foglalkoztattak, ezzel szemben a pécsi gyárban ugyanebben az évben 690 fó volt a dolgozói létszám (Foglalkoztatás 1900).

A képzett, de ugyanakkor drága munkaeró Zsolnayt arra sarkallta, hogy megpróbálja a gyár dolgozói utánpótlását legalább részben belső erőből pótolni. 1886-ban gyári tanonciskolát állított fel, ahol a fiatalok általában a gyári alkalmazottak gyermekei közül kerültek ki. A gyári iskolában a városból érkezett tanárok tanították a közismereti tárgyakat, a szaktárgyakat pedig a gyár müvészei vállalták fel (Rúzsás 1954. 66). A cél egyértelmüen az olcsóbb, hazai rekrutációjú munkásbázis megteremtése volt. Ez a századforduló környékére sikerült is a nagyvállalkozónak: a századforduló idejére már túlsúlyba kerültek a hazai származásúak. Ebbe persze az is belejátszott, hogy sok külföldröl jött letelepedett, családot alapított, s gyermekeik már itt születtek.

\section{A tradicionális szakmai ismeretek meg- újítása: a Hamerli kesztyügyár esete A Traditional Trade Renewed: The Case of the Hamerli Glove Factory}

A pécsi innovatív vállalkozások harmadik eseteként a „pécsi kesztyü” létrehozójával, Hamerli Jánossal, Magyarország első kesztyűgyárának alapítójával foglalkozunk. Hamerli életútja tipikusan jellemzi a korabeli, kevés tőkével, de nagy szaktudással rendelkező vállalkozói pályalehetőséget. Hamerli apja az 1830-as években került Baranyába, ahol Püspöknádasdon (ma Mecseknádasd) püspöki hajdúként szolgált. 1834-ben házasodott meg, a harmadik gyermek, János már Pécsett látta meg a napvilágot 1840-ben (Déri és tsai 2016. 48). Hamerli János tímármesterséget tanult, majd ipari vándorútra ment, amelynek során Temesváron és Aradon, Pesten, Grácban és Bécsben tanulmányozta mesterségét. 1861-ben önálló vállalkozói tervekkel érkezett haza, s kérvényezte a pécsi városi tanácstól, hogy önálló kesztyüs mesterséget üzhessen. Ezt a kérését a hivatal kiskorúsága miatt elutasította, ám Hamerli megkerülte a problémát: nagykorúsította magát, s így a tanács hozzájárulhatott a mesterség üzéséhez szükséges iparengedély kiadásához (Déri 1977. 22-23; Sey 2005).

Hamerli apja házában, a Kis Flórián utca 8. szám alatt rendezte be első kis mühelyét, ám nem sokkal később áthelyezte üzemét a Fő utca 5. szám alá, amely épületet kezdetben bérelte (Déri 1977. 23). Hamerlit ebben az időben kesztyükészítőként tartották nyilván a városi iratok. Jegyezzük meg, hogy a Fő utca elején lévő épület igen frekventált mühelyt és lakóházat jelentett. Nem tudjuk pontosan, hogy Hamerli mekkora tőkeerővel kezdte vállalkozását, ám minden bizonnyal volt valamennyi felhalmozott (talán örökség, vagy tanuló és kezdő évei alatt gyüjtött) pénze, hiszen a bérleti díj sem lehetett olcsó; ugyanakkor tudjuk azt is, hogy üzeméhez már gépeket is vásárolt az 1860-as évek vége felé (Sey 2005. 114). Jól mehetett az üzlet, amit az is mutat, hogy 1865-ben Bécsben kérelmezte, hogy kesztyükészítö üzemet nyithasson s ugyanakkor lakhatási engedélyt kaphasson. Hamerli vándorévei alatt felmérte a bécsi piaci pozíciókat, s tudta, hogy jó minőségü kesztyükkel biztos keresletre találhat a birodalmi fővárosban. A bécsi üzemet 1874-ig működtette a pécsi vállalkozó, eközben megszakításokkal, de családja is ott élt (Déri és tsai. 2016. 49.).

A piacok szélesedése folyamatos üzembővítésre késztette a vállalkozót. A Fő téren lévő Városháza épületében üzletet tartott fenn, egészen 1888-ig. 
A növekedés egyik jele a telephelyek szaporodása volt. Szembe kellett azzal néznie, hogy a polgárosodó Pécsett a város közepén egy környezetszenynyező és büzös bőrüzemet múködtetni sokáig nem lehet, nem is beszélve arról, hogy az üzem méretének növelése is akadályba ütközött. Hamerli így újabb és újabb pécsi telkek és házak megvásárlására kényszerült. 1877-ben megvásárolta az Alsó-Puturla utcában a 13. szám alatti telket, a rajta lévő kordovános mühelyekkel, ahova előbb nyersbőr raktárát, idővel pedig tímármühelyét kiköltöztette (Déri 1977).

A többi ingatlanvásárlása már más célt szolgált. Számos kisebb-nagyobb telket, földbirtokot vásárolt, amit igyekezett magasabb áron értékesíteni (Déri és tsai 2016. 52). Az 1870-es évek második felében megvette az üzemtől nem messze lévő Mária utca 21. szám alatti épületet a hozzá tartozó udvarral együtt. 1883-ban a Szigeti városrészben vett egy házat, udvarral és kerttel, majd pedig ugyanabban a városrészben a „Három varjú” kocsmát vásárolta meg. Tökéjének egy részét személyfuvarozási vállalkozásba fektette, a lovak ellátására a Postavölgyben vásárolt telket (Sey 2005. 114). Akár csak Zsolnay, Hamerli is igyekezett biztonságos befektetéseket (ingatlanvásárlás) találni vagyona gyarapítására.

Hamerli János a hazai piac mellett kezdettől fogva próbálta erôltetni a külföldi értékesítést is. A Monarchia közös piaca a századforduló környékén a maga 40 milliós népességével biztos felvevőpiacot jelentett, de a nagy ugrást mindenképpen az állami megrendelések biztosították. A közös hadsereg óriási és biztos piac volt. Hamerli az 1880-as évek elején már évi 45.000 pár kesztyüt szállított a hadsereg számára. Ám azt sem szabad elfelejtenünk, hogy a pécsi vállalkozó a divat szempontjából is meghatározó volt az országban; egyre több nagy hazai kereskedő vásárolta meg áruit. A Monarchián belüli sikereken túl a századforduló környékén a pécsi kesztyük megjelentek Nyugat-Európa városaiban is. Az évi termelés az 1890-es évek közepe felé kb. 80-100.000 pár kesztyü volt (Várady 1896. 625).

A dualizmus korában alapozódott meg a minőségi „pécsi kesztyű” fogalma. A jó kesztyű létfontosságú eleme a jó alapanyag. Hamerli saját üzemében alapvetően nem vásárolt bőrből, hanem az önmaga által készített börökből varratta termékeit (Lenkei 1922. 209.; Ágh 1894. 251). Termékei minőségét mutatják a vásári díjak és árubemutató-elismerések. Az 1873. évi bécsi világkiállításon érdeméremmel, az 1875. évi neusalzi ipari kiállításon aranyéremmel, míg az 1876. évi philadelphiai világkiállításon elismerő oklevéllel jutalmazták.
De ott szerepelt a hazai kiállításokon is, ahonnan szintén sok érmet, helyezést vihetett haza (Déri 1977. 49-50). A jó minőségü kesztyüiröl elhíresült Hamerli egy sikeres pécsi vállalkozó fogalmaként vonult be a köztudatba. Ebben a korszakban a pécsi volt az egyetlen kesztyügyár az országban, a Monarchián belüli versenytársak a csehországi üzemek voltak.

A jó alapanyag mellett persze technika is kellett a minőséghez. A kesztyügyártás sokáig, régi módszerek alapján, teljesen kézi szabással és varrással készült. Az 1830-as évektől azonban Nyugat-Európában már érdemi kísérletek történtek a különböző szabásminták kialakítására, amivel a termelékenységet tudták növelni. Az igazi nagy áttörés 1867ben következett be, amikor is feltalálták a kesztyűvarrógépet. Az új technika hamar megjelent a minőségre sokat adó Hamerli-féle pécsi üzemben is. 1868-ban már nyugati présgépet vásárolt, megvett egy kivágókalibert, majd pedig folyamatosan szaporodtak a varrógépek, amelyekböl az 1870es évek végére már kb. 50 darab volt az üzemben (Várady 1896. 625).

A gazdasági elörelépés másik tényezője a munkaerő biztosítása volt. Hasonlóan a kerámiagyártáshoz, a börgyártás legtöbb fázisa is speciálisan képzett munkaerőt igényel. Az ipari továbbfelhasználásra kikészített bőröket igen sok munkafázison kell keresztülvinni, így például konzerválni, áztatni, meszezni, kopasztani, húsolni, színelni, hasítani, mészteleníteni, pácolni, cserzeni, hántolni, puhítani stb. kell. Kezdetben a magas minőségü bőrgyártó területekröl kellett behívnia szakembereket. 1878ban már 77 munkás dolgozott a gyárban, akik közül 50 varrónő volt. (Déri 1977. 58.) Továbblépésre akkor volt lehetőség, amikor a 20. század első éveiben megépült a kesztyúgyár új egysége. Az állami szubvencióról szóló szerződés szerint 1905-re el kellett érnie a 200 fős foglalkoztatást, amit az új üzem felépítésével gond nélkül teljesítettek, vagyis a cég a világháború előtti időszakban gyors munkaerö-bővítésen ment át (Lásd: Foglalkoztatás 1910. 1242.; T. Mérey 1999). 
A nyugati technikai színvonal meghaladása: az Angster-orgonagyár Overperforming the Western Technological Standard: The Angster Organ Manufactory

Pécsett mindig is nagy jelentősége volt a fémiparnak és a faiparnak. A fémipar területén rézmüvesmühelyek, lakatosműhelyek nagy számban fordultak elö, de említettük korábban a reformkori vasgyár megalapítását is. Ugyanez mondható el a faiparról, s azon belül az asztalosokról, akik szintén magas arányban voltak jelen az iparosok között. E két iparág kapcsolódásából jött a hangszerkészítés, amelyben a pécsi Angster József orgona- és harmóniumgyára vált messze földön híressé.

Angster József 1834-ben született, a délkelet-dunántúli Kácsfaluból származott. Falusias körülmények között, egy nádfedeles vályogházban nőtt fel. Állítólag már gyermekkorában kis hangszereket készített és muzsikált is (Angster 1999. 75; Angster 2017). Angsternek nem voltak orgonakészítő ősei; szülei 1850-től iparostanoncnak adták Eszékre, ahol asztalosnak tanult, majd iparos vándorútra ment. Két évig Temesvár környékén, majd tíz évig nyugat-európai területeken tanulta az orgonakészítői mesterséget (Pécs Lexikon 2010. 1. 39). Az akkor elérhető legmagasabb képzettséggel tért haza. 1867-ben telepedett le Pécsett, s hozta létre saját vállalkozását. Viszonylag sok megrendelést kapott, első jelentősebb orgonája 1869. március 21-én szólalt meg először a pécsi zsinagógában (Angster 1999. 74).

A folyamatos fejlödés eredményeképpen a vállalkozás dinamikusan növekedett, az 1890-es évek elején 50-60 munkást, míg a világháború előttti időkben különböző források szerint már 110-120 embert foglalkoztatott (Thirring 1912. 303). A cég növekedése során mindig kinőtte üzemi helyiségeit, ezért állandóan költöznie kellett, az ötödik költözködés eredménye már egy végleges telephely lett: a József utca 30. szám alatti telken rendezkedhetett be az orgonagyár tulajdonosa, amihez a későbbiekben megszerezte a Mária utca 35. számú ingatlant is (Pécs Lexikon 2010. 1. 39). Így együttesen a belváros északi részén egy igen kiterjedt, többemeletes épületekkel rendelkező gyáregység jött létre. Az üzemben egy 4 LE gőzgépet működtettek, amivel fürészeket, esztergákat hajtottak meg. Alapanyagot részben hazai kereskedőktől vásárolt, ugyanakkor importból, föleg angol területekről szerezte be az ónt és az ólmot (Várady 1896. 605). A 100. orgonát a pécsi székesegyház számára készítette 1889-ben, amit az épület újjáépítésének elhúzódása miatt csak 1891-ben avattak fel (Angster 1999. 79).

A gyár növekedése állandó technikai és technológiai fejlesztéseket feltételezett, ennek során 1909ben - felhasználva az állami segélyt is - Diesel-motoros hajtással több, mint egy tucat munkagépet telepítettek a gyárba (Angster 1999. 81). A piac adott volt, s mivel igen magas minőségü termékekről volt szó, így egyre jelentősebb intézmények számára szállíthattak Angster-orgonát. Csak néhány példa a hazai nevezetesebb helyekről: a pécsi és a kassai székesegyház, a budapesti Kálvin téri templom, a szintén fővárosi Szent István Bazilika, a pécsi belvárosi templom, a győri, a kolozsvári templom stb. (Angster 1999. 78). Nagyon lényeges ugyanakkor az export is: az Angster-orgonák gyorsan meghódították az osztrák piacot is, kiszorítva onnan a nyugati termelőket. A korabeli Pécsi Közlöny híradása szerint (1903.04.07) a legnagyobb üzleti ellenfél az ausztriai székhelyü, de budapesti üzemmel is rendelkező Rieger-testvérek gyára volt, amellyel szemben elnyerték a budapesti bazilika orgonagyártási megbízását.

A gyors piachódítást az Angster-orgonák minősége támasztotta alá. Angster nemcsak adaptálta a nyugat-európai építőtechnikát, hanem tovább is fejlesztette azt, s így a történeti Magyarország legkiválóbb orgonáinak építője lett (Szita 1995. 133134). Ezen újítások közül nem egy az orgonatechnika történetében zseniális találmánynak számított. A technikát folyamatosan fejlesztette. Eleinte még csak 12-20, később már 40, a budapesti bazilika esetében pedig már 65 regiszteres orgonát gyártott. Az Angster-gyár önmagában nem volt nagy gyár, inkább közepesnek mondható, ám a korszerü gyártástechnológia végeredményével nagyon mélyen beírta magát a város történetébe. Az alapító gyártulajdonos 1918-ban halt meg, a gyár két fia (Emil és Oszkár) kezén öröklődött tovább (Pécs Lexikon 2010. 1. 40).

\section{Egy igazi self made man: Engel Adolf A Real Self-Made Man: Adolf Engel}

Van egy igen érdekes alakja a helyi innovatív vállalkozóknak, mégpedig Engel Adolf, aki az egyik legsikeresebb vállalkozó volt Pécsett a dualizmus korában. Munkássága igen érdekes vállalkozói stratégiát mutat. Az izraelita családból származó Engel a semmiből indult, s egyéni akaraterejéből vált a város egyik meghatározó üzletemberévé. Engel Adolf 11 évesen már maga kereste a kenyerét, utcai kereskedelem formájában árult különféle értéktelen tárgyakat, szabad idejében pedig egy fütetlen szo- 
bában olvasott és tanult (Jánosi Engel 2009). Engel 16 évesen már 160 forintos megtakarítással rendelkezett. Dohányvásárlásokba kezdett, Godisáról vásárolt dohányt, ,,...heteket töltve el a dohánymezökön, éhezés és nélkülözés közepette, csak szilvát és kenyeret fogyasztva" - írta róla a jelenkor krónikása (Szirtes 1998. 46). Házassága révén stabilizálódott a helyzete, a Lyceum utcában nyitott bútorés ruhaüzletet, ahol az üzletmenet érdekében néha még a bútorait is eladta, $\mathrm{s}$ a földön aludt.

Engel Adolf figyelme a 19. század közepén egyre inkább az építőipar és a faipar felé fordult. A faipar számos ágazatának a növekedő város, a szaporodó épületek, s az egyre magasabb minőséget elváró társadalom kereslete állandóan lehetöségeket biztosított. Ne felejtsük el, hogy néhány ipari ágazat fejlődése óriási mennyiségü faanyagot igényelt (vasút, bányászat, hajózás, építőipar). Az 1850-es évektől Pécsett valóságos építkezési láz tört ki, amely során egyre több középületet emeltek, aminek jelentős faigénye volt. Kortársi adatok szerint 1844-1894 közötti ötven év alatt 27 középületet hoztak létre a város költségén, s akkor még nem is beszéltünk a magánerős lakásépítkezésekről és a gazdasági beruházásokról (Ágh 1894. 216-217). A vasút megjelenése is jelentős hatást gyakorolt a fakeresletre, s külön ki kell emelnünk Engel Adolf üzleti lehetőségei közül a DGT pécsi bányáinak faszükségletét, amely óriási piacot biztosított a vállalkozó számára. 1863-ban gőzfürészeléssel kezdett foglalkozni, majd pedig parkettagyárat létesített (Vörös 1999. 133-138). Engel Adolf pécsi faipari vállalkozása a városában $70-100$ föt foglalkoztatott, ám ha az üzemhez hozzátesszük az általa a fakitermelésben, szállitásban stb. foglalkoztatottak számát is, akkor már egy 250-300 fövel múködő vállalkozás képe sejlik fel a kutató előtt (Várady 1896. 608).

A parkettagyár építése már 1860-ban elkezdődött, amit aztán a tőkeerőnek megfelelöen folyamatosan bővítettek. Az 1890-es évek elején a gyár már egy kazánhelyiséggel, egy gépházzal, három részből álló fürészüzemmel, faaprító mühellyel, valamint szárító és feldolgozó helyiséggel rendelkezett. Emellett volt a gyár területén lakatos-, asztalos- és kovácsmúhely is. Nagyon lényeges volt a nagy tömegủ fa szállítása szempontjából, hogy az ipartelepet a vasúttal egy iparvágány kötötte össze, amely mellett egy jelentős méretű faraktár helyezkedett el. A gyári gőzgépek teljesítménye az 1890-1910 közötti korszakban különböző adatok szerint együttesen mintegy 80 LE-t tett ki, a gőzgépekhez tüzelőanyagként kőszenet, fahulladékot és fürészport használtak. A gyár az 19 század vége felé már villanyvilágítással is rendelkezett, évi ter- melöképessége $8000 \mathrm{~m}^{3}$ metszett anyag és 25.000 $\mathrm{m}^{3}$ talajkocka-parketta volt. A nyersanyagot Svájcból és a karintiai területekről szerezte be. Sokfajta fával foglalkoztak: tölgyfát, diófát, kőrisfát, szilfát, bükköt és fenyőfát egyaránt feldolgoztak. Ismert volt a vállalkozó szociális érzékenységéről, munkásait viszonylag jól fizette, s különböző szociális juttatásokban részesítette őket (Várady 1896. 608).

Az Engel Adolf-féle cég komoly piaci eredményeket és egyben minőségi elismerést szerzett a dualista korszak első időszakában (Ágh 1894. 241). Számos díjat nyertek el. 1864-ben az Országos Iparegyesület ezüstérmét kapta a cég a versenyképességért. Díjai közül kiemelkedik az 1878. évi párizsi világkiállításon szerzett aranyérem, a bécsi és a budapesti aranyérem, valamint az 1888 . évi pécsi kiállítási aranyérem. Az Engel-vállalat egyre inkább a Monarchia keretrendszerében gondolkodhatott (Vörös 1999. 133-138). Engel Adolf 1884-ben megvette Barawitzka-féle parkettagyárat az ausztriai Ober-Döblingben. Egy évvel később. Dél-Dunántúlon is terjeszkedett a vállalat, így például 1878-ban megnyitották a barcsi és a szigetvári fióktelepeket. Ezen kívül Szentlörinc is bekerült a vállalat érdekkörébe, ahol 1892-ben állította föl Engel Adolf a gőzfürész-telepet, amely $7200 \mathrm{~m}^{2}$-en helyezkedett el, s évi $3000 \mathrm{~m}^{3}$ készített, 30 munkást dolgoztatva (Várady 1896. 608).

Érdekes ugyanakkor, hogy Engel Adolf faipari vállalkozásai mellett alapítói munkája hihetetlen széleskörüvé vált. Az 1850-es évek közepe felé megnyitotta a város első szénraktárát. 1856-ban három pécsi polgárral együtt elkezdte a balokányi uszoda felépítését, amit aztán majd egyedül fejezett be. 1860-ban megvásárolta 20.000 Ft-ért a Czindery-kertet a hozzátartozó fürdővel együtt (Kaposi 2019/a; Jánosi Engel 2009). Jelentős volt a házépítési tevékenysége, így például ö építtette fel a Széchenyi tér és a Perczel utca sarkán álló ún. Lóránt-palotát, amely a város egyik rangos épülete lett. A Rákóczi úton is épített egy kétemeletes házat, s a Hal tér sarkán is az ő háza állt (Vörös 1999). $S$ végül ne felejtsük el a köszénbányászat területén végzett kutatásait és vállalkozását, ami a komlói szénkitermelés elindítását hozta (Szirtes 1998). Mindebből látható, hogy Engel Adolf esetében vállalkozásai, cégalapításai igen sokrétüek, amiben pénzt érzett, azt megragadta.

Az igen szép kort megélt Engel Adolf a 19. század vége felé Bécsbe költözött, a pécsi cégben végzett munkájától visszavonult. Ez persze nem hirtelen jött ötlet volt, a vállalat már 1876-tól amúgy is átalakult, hiszen két fiát bevonta a vezetésbe, $\mathrm{s}$ Engel Adolf és fiai néven társas vállalkozássá szervezte át cégét. A faipari cég az alapító 1903-ban 
bekövetkezett halála után is tovább müködött, bár addigra már megváltoztak a külső feltételek: az építési konjunktúra lendülete is megtört, s a bányák is kiépültek Pécs környékén.

\section{ÖSSZEGZÉS SUMMARY}

Pécs gazdasági fejlődésében a dualizmus korában egyértelmúen az iparosodás játszotta a fő szerepet. A pécsi iparosodás ugyan nem hozott létre koloszszális méretü ipari üzemeket, de a foglalkoztatásban, a jövedelemtermelésben, a pécsi értékrendben, a mentalitásban meghatározó szerephez jutott. A dualizmus korában a város iparszerkezetében a gyorsan kiépülő gyáripar adta a dinamizmust. A félévszázados időszak alatt világhírü vállalatok és találmányok születtek a városban. Az ekkor létrejött ipari kapacitások közül néhány (bár lecsökkent méretben és más tulajdonszerkezetben) ma is müködik (kesztyügyártás, Zsolnay-gyár stb.), befolyásolva a város és társadalma működését.

\section{HIVATKOZÁSOK REFERENCES}

Abel, W. (1935), Agrarkrisen und Agrarkonjunktur in Mitteleuropa vom 13. bis zum 19. Jahrhundert. Berlin: Paul Parey

Ágh, T. (1894), Emléklapok Pécs szabad királyi város múltjából és jelenéböl. Pécs: Taizs József

Angster, J. (1999), „Az Angster-család és az Angster orgonagyár történetéböl", in: Szirtes G. Vargha D. (szerk.), Angstertől Zsolnayig, Pécs: P-BKIK, Pro Pannonia

Angster, J (2017), Életrajzom. Egy XIX. századi orgonaépítő naplója. Budapest: Rózsavölgyi és Társa

Antalffy Gy. (1982), Reformkori magyar városrajzok. Budapest: Panoráma

Babics A. (1952), A pécsvidéki kőszénbányászat története. Budapest: Akadémiai

Bácskai V. (1988), Városok és városi társadalom Magyarországon a XIX. század elején. Budapest: Akadémiai

Bairoch, P. (1976), „Die Landwirtschaft und die Industrielle Revolution 1750-1914”, in: Cipolla, C. M. / Borchardt, K. (Herausg.), Die Industrielle Revolution. Europäische Wirtschaftsgeschichte. Band 3. Stuttgart: Fischer

Berend T. I. - Ránki Gy. (1987), Európa gazdasági fejlödése a 19. században. Budapest: Gondolat

Bobrovszky I. (1971), ,Zsolnay kerámiák az 1885ös országos általános kiállításon”, in: Hárs Éva - Mándoki László (szerk.), 100 éves a Pécsi Porcelángyár, Pécs: FIM Pécsi Porcelángyár, JPM

Cameron, R. (1989), A Concise Economic History of the World. From Paleolithic Times to the Present. Oxford: University Press

Crafts, N. F. R. (1985), British Economic Growth during the Industrial Revolution. Oxford: Clarendon

Déri J. (1977), „A pécsi kesztyüipar kialakulása és története a Hamerli kesztyügyár államosításáig", in: Déri J. (szerk.), A Pécsi Kesztyügyár története 1861-1976. Pécs: Pécsi Kesztyügyár

Déri J. - Gál É. - Márfi A. (2016), Kesztyükönyv. Pécs: JPM

DGT (1894), Az I. cs. k. szab. Dunagözhajózási Társulat Pécs melletti köszénbányái. Pécs: DGT

Erdősi F. (1986), „Baranya közlekedési hálózatának fejlődése a XIX. század második felében,” in: Szita L. (szerk.), Baranyai helytörténetírás 1985-1986. Pécs: BML 
Estók J. (1996), A mezőgazdasági gépgyártás története Magyarországon a kezdetektől 1944 ig. Budapest: MMGM

Fényes E. (1851), Magyarország geographiai szótára. I-II. kötet. Pest: Nyomatott Kozma Vazulnál

Good, D. (1986), Der wirtschaftliche Aufstieg des Habsburgerreiches 1750-1914. Wien-KölnGraz: Böhlau

Huszár Z. (2013), A Duna vonzásában. Fejezetek a Dunai Gözhajózási Társaság történetéböl. Pécs: Virágmandula

Jánosi Engel A. (2009), Életemből. Pécs: Pannonia Könyvek

Jávor K. (2004), „A Zsolnay család. Iparosok és müvészek öt nemzedéke”, in: Sebők M. (szerk.), Sokszínü kapitalizmus. Budapest: HVG Kiadó

Kaposi Z. (1996), A gazdasági folyamatok és a közgazdasági gondolkodás kapcsolata a 18. században. Pécs: JPTE Kiadó

Kaposi Z. (2002), Magyarország gazdaságtörténete 1700-2000. Budapest-Pécs: Dialóg Campus

Kaposi Z. (2006), Pécs gazdasági fejlödése 1867 2000, Pécs: P-BKIK

Kaposi Z. (2017), „Pécs gazdasági helyzete a 19. század közepén,” Közép-Európai Közlemények, 10(37). 7-22

Kaposi Z. (2019/a), „Uradalmak, földbirtokosok és birtokforgalom a Dél-Dunántúlon a 19. században," Mezögazdaság--történeti Tanulmányok 14 Budapest: Magyar Mezőgazdasági Múzeum és Könyvtár

Kaposi Z. (2019/b), „Pécs iparának változásai a Trianon utáni évtizedben." Közép-Európai Közlemények, 12(47) 161-174

Katus L. (1989), „A Monarchia közös piaca”. Magyar Tudomány, 34(10-11), 808-820.

Komlos, J. (1990), Az Osztrák-Magyar Monarchia, mint közös piac. Budapest: Maecenas

Kopasz G. (1968), A répacukorgyártás kezdete a Dél-Dunántúlon (1837-67), in: Szinkovich M. (szerk.), Baranyai helytörténetírás 1968. Pécs: BML

Kovács A. (1973), „Adatok a pécsi filoxéravész történetéhez," in: Szita L. (szerk.), Baranyai helytörténetírás 1972. Pécs: BML

Kövér Gy. (1982), Iparosodás agrárországban, Budapest: Gondolat

Landes, D. (1969), The Unbound Prometheus: Technological Change and Industrial Development in Western Europe from 1750 to the Present. Cambridge, New York: Press Syndicate of the University of Cambridge

Lenkei L. (1922), Negyven év Pécs életéböl. Egy pécsi újságíró visszaemlékezései, Pécs: Pécsi
Irodalmi és Könyvnyomdai Részvénytársaság

Mattyasovszky-Zsolnay T. (1999), ,Adatok a pécsi Zsolnay-család történetéhez,” in: Szirtes G. Vargha D. (szerk.), Angstertől Zsolnayig, Pécs: P-BKIK, Pro Pannonia

Orosz, I. (1971), „Die landwirtschaftliche Produktion in Ungarn 1790-1849”. Agrártörténeti Szemle 13 Supplementum. 1-24

Overton, M. (1996), Agricultural Revolution of England. The transformation of the agrarian economy 1500-1850. Cambridge: University Press

Pálfy A. (2002), „A pécsi székesegyház önálló uradalmi szénbányászata (1798-1868)," in: Szirtes G. - Vargha D. (szerk.), Iparosok és bányászok a Mecsekalján. Pécs: P-BKIK, Pro Pannonia

Ránki Gy. (1983), „Az angol ipari forradalom történetéhez", in: Ránki Gy. (szerk.), Mozgásterek, kényszerpályák. Válogatott tanulmányok, Budapest: Magvető

Remport Z. (1996), „A reformkor kiemelkedő ipari kísérlete: a Csetnek Pécsi Vasgyár." Századok, 130(1) 105-118

Romváry, F. (2011), Zsolnay. Debrecen: Tóth Könyvkereskedés és Kiadó

Rúzsás L. (1954), A pécsi Zsolnay-gyár története. Budapest: Akadémiai

Schultz, Th. (1964), Transforming of Traditional Agriculture. New York: Yale University Press

Schumpeter, P. (1980), A gazdasági fejlödés elmélete, Budapest: KJK

Sey, G. (2005), „A pécsi Hamerli-Hunor kesztyügyár. Emlékezés a cég alapításának 142., a gyár megnyitásának 100. évfordulójára", in: Szirtes G. - Vargha D. (szerk.), Mozaikok Pécs és Baranya gazdaságtörténetéböl. Pécs: P-BKIK, Pro Pannonia

Slicher van Bath, B. H. (1963), Agrarian History of Western Europe, A.D. 500-1850, London: Arnold

Sombart, W. (1909), Der kapitalistische Unternehmer, Archiv für Sozialwissenschaft und Sozialpolitik 29 689-758.

Szabad Gy. (1978), „Az önkényuralom gazdaság- és társadalompolitikája", in: Kovács E. (föszerk.), Magyarország története 1848-1890. 2. kötet. Budapest: Akadémiai

Szirtes G. (1998), Pécsi Panteon. Portrék a millenium korából, Pécs: Pro Pannonia

Szita L. (1995), „A pécsi vállalkozó polgárság és a helyi hatalom a 19. században", in: Fodor Zs. (szerk.), Vállalkozó polgárok a Dunántúlon a dualizmus korában. Veszprém: Laczkó Dezső Múzeum 
Taylor, D. (1988), Mastering Economic and Social History, London: Macmillan

Thaer, A. (1810), Grundsätze der rationellen Landwirtschaft, Berlin: Universität Berlin

T. Mérey, K. (1999), „Baranya megye ipara (18501914)", in: Szirtes G. - Vargha D. (szerk.), Angstertöl Zsolnayig, Pécs: P-BKIK, Pro Pannonia

Tóth T. (1982), Ellentét vagy kölcsönösség? A magyar mezögazdaság üzemi viszonyainak történeti háttere és problémái, Budapest: Magvető

Turner, M. E. (1989), „Parlamentary Enclosures: Gains and Costs", in: Digby, A., Feinstein Ch. (Eds.), New Directions in Economic and Social History. London: Macmillan

Várady F. (1896), Baranya multja és jelenje, 1-2 kötet. Pécs: Telegdi Ármin Könyvnyomda

Vargha D. (1999), ,Zsolnay Miklós életútja (18571922)," in: Szirtes G - Vargha D. (szerk.), Angstertől Zsolnayig. Pécs: P-BKIK, Pro Pannonia

Vörös A. (1999), „Jánosi Engel Adolf (18201903)," in: Font M. - Vonyó J. (szerk.), Tanulmányok Pécs történetéből 5-6. Pécs: Pécs Története Alapítvány

Zsolnay T. (1974), Zsolnay. A gyár és a család története 1863-1948, Budapest: Corvina

\section{Hivatkozott forrásgyüjtemények és} statisztikák

\section{Annotated published sources and} statistics

Foglalkoztatás (1900), A magyar korona országainak 1900. évi népszámlálása. Ötödik rész. A népesség foglalkozásának némely részletei és a vállalati statisztika, Budapest: $\mathrm{KSH}$, 1906.

Foglalkoztatás (1910), A magyar szent korona országainak 1910. évi népszámlálása. Harmadik rész. A népesség foglalkozása részletesen és a vállalati statisztika, Budapest: KSH, 1914.

Nagy, L. (1828), Notitae politico-geograhico statisticae inclyti regni Hungariae partimque eidem adnexarum. I-II., Buda: Landerer

Pécs ezer éve (1996), Márfi A. (szerk.), Pécs ezer éve 1009-1962. Pécs: Pécs Története Alapítvány

Pécs Lexikon (2010), Romváry Ferenc (szerk.), Pécs Lexikon I-II. kötet. Pécs

Thirring G. (1912), A magyar városok statisztikai évkönyve. 1. évf. 1-2. kötet. Budapest

\section{A tanulmányhoz felhasznált, de hivat-} kozásokban külön nem jelzett levéltári fondok

\section{Thematic sources of archives used but not annotated}

Magyar Nemzeti Levéltár Baranya Megyei Levéltára (=MNL BML)

MNL BML XI. 6. Angster József és Fiai Orgonaés Harmóniumgyár iratai (1860-1949)

MNL BML XI. 8. Hamerli Kesztyügyár iratai (1903-1948)

MNL BML XI. 10. Zsolnay Vilmos Kerámia Gyárak iratai (1874-1960)

MNL BML XI. 13. Pannónia Sörfőző Rt, Pannónia Sörgyár iratai (1904-1972)

MNL BML XI. 23. Pécsi Bőrgyár iratai (19041990) 


\section{Entrepreneurs, Enterprises and Innovations in Pécs in the Time of the Dual Monarchy}

\section{THE AIMS OF THE PAPER}

To examine how the $19^{\text {th }}$ century economic modernisation (Western type of industrialisation, technological transformation and the birth of the manufacturing industry) unfolded in Central Europe; and more importantly in Hungary, in Pécs, and what technological innovations were created by local entrepreneurs.

\section{METHODOLOGY}

Literature review including the history of the manufacturing industry. We involved sources from monographies, employment and census records, reminiscences and our own data from researches of archives. The research framework is the history of distinct businesses. We introduced five businesses whose economic effects influenced the operations of Pécs in the long run. We made a structural analysis examining the entrepreneur and its business together.

\section{MOST IMPORTANT RESULTS}

The Austrian First-Danube-Steamboat-Shipping Company (DDSG) became the largest works in the city by starting the intensive coal mining and creating modern technological background since 1852. It employed four thousand souls in the beginning of the $20^{\text {th }}$ century and the city profited a lot from its developments (railway construction and electric power plant). The Zsolnay Porcelain Manufactory has quickly become the synonym of Pécs. Vilmos Zsolnay ended up being a world famous entrepreneur because of his technological innovations (eosin, pyrogranite, etc...) and products. The term "Glove of Pécs” came alive in the ages of the dual monarchy. János Hamerli founded the first glove manufacturing plant in the country. The Angster Organs have being played for hundred and fifty years. The company founded by József Angster emerged at the end of the $19^{\text {th }}$ century and represented state of art technology. The multitalented Adolf Engel's businesses aided the spa culture (Balokány), the wood industry, the construction industry and the coal mining at Komló.

\section{ECONOMIC POLICY RECOMMENDATIONS}

The innovations and the economic development were promoted by the dominant policy of the era, the economic liberalism; the liberal entrepreneur environment, the huge market of the Dual Monarchy, the technological creativity and the increase in the populations' needs.

Keywords: Pécs, city, entrepreneur, company, innovation, development

Acknowledgements: This publication/research has been supported by the European Union and Hungary and co-financed by the European Social Fund through the project EFOP-3.6.2-16-2017-00017, titled "Sustainable, intelligent and inclusive regional and city models”. 